Han, W. McCabe, S. Wang, Y. \& Chong, A. (2017). Evaluating user-generated content in social media: an effective approach to encourage greater pro-environmental behaviour in tourism?

Forthcoming in the Journal of Sustainable Tourism.

http://dx.doi.org/10.1080/09669582.2017.1372442

Author final version prior to proof changes

\title{
Evaluating user-generated content in social media: an effective approach to encourage greater pro-environmental behaviour in tourism?
}

\section{Key words: Pro-environmental behavior, User Generated Content, Social media, Tourism marketing, Norms}

\begin{abstract}
Appealing to tourists' intrinsic interest for high quality tourism environments, and thus encouraging them to act with a greater sense of personal responsibility towards the environment, could be critical to promoting sustainable tourism. Proliferating media channels makes the choice, style and delivery of pro-environmental messages a key issue for tourism marketers and management. Social media has become a recognized important channel for tourism information, with user-generated content (UGC) being more trusted than official channels, yet there is little knowledge about its potential role in activating pro-environmental norms. This study investigates that issue. Focusing on the conjoining aspects of personal and social norms for the first time, we propose a hypothetical model to explain the direct and indirect effects of pro-environmental UGC in activating tourists' pro-environmental behavioral intentions. Working in a Chinese context, where social media plays an increasing role, the research, using a web based sample, $(\mathrm{N}=1043)$, UGC linked pro-environmental knowledge and awareness was found to have a strong role in activating pro-environmental norms, creating a proenvironment online community, and increasing tourists' level of engagement in pro-environmental social media activity. The study highlights the effectiveness of social media channels with UGC providing persuasive communications able to impact sustainable behaviors.
\end{abstract}

\section{Introduction}

Pro-environmental behavior describes an action by an individual or group that promotes or results in the sustainable use of natural resources (Ramkissoon, Smith, \& Weiler, 2013). Globally, consumers' environmental consciousness has increased in recent decades. These changes have been driven by a variety of factors including: greater awareness, public pressure, environmental legislation, increased media coverage and changed public opinion (Charter, 1992; Tapon \& Leighton, 1991). However, the tourism industry is still "far from sustainable" (Buckley, 2012, p.534). Environmental issues must be taken into account because destination 
competitiveness and indeed, many tourist activities directly depend on the quality of natural resources of destinations. Attracting tourists who have an intrinsic interest in protecting the environment and consequently develop more pro-environmental attitudes and behavior is an important component in promoting sustainable tourism.

Efforts to understand and predict consumers' environmental behavior have generated a large body of literature, much of which investigates the issues based on the assumption that behavior is the outcome of a linear and rational process of decision making (Hargreaves, 2011). This literature has suggested that categories of variables (e.g. social, situational and psychological) motivate pro-environmental behavior (Barr \& Gilg, 2007). However, these variables have been criticized for insufficiently explaining pro-environmental behavior, because the relationship between knowledge and attitudes, attitudes and intentions, and intentions and actual behavior, are weak at best (Kollmuss \& Agyeman, 2002).

Particularly, there has been intense debate concerning the gap between attitudes and intentions, which represent planned purchases and actual behavior (consumption decisions). Despite these criticisms, intentions remain the best indicator for behavior (Harland, Staats, \& Wilke, 2007; March \& Woodside, 2005). Additionally, moral and normative approaches have been shown to be more effective than attitudes in explaining behavioral intentions, particularly where there is environmental intent (Steg \& Uneken, 2004). And so, this study focuses on norms and proenvironmental behavioral intentions, rather than attitudes. Norm Activation Theory provides a rational perspective on how personal norms can be activated through a process of generating awareness of the consequences through to the transformation of moral norms and to actual behavior change (Schwartz, 1977). However, Klöckner and Blöbaum (2010) argued that Norm Activation Theory contains limitations as it overlooks the social (situational) influences on people. Social Norm Theory is, therefore, used together with Norm Activation Theory in this study to explain the formation of pro-environmental behavioral intention.

Concurrent with increased environmental awareness and concern, users of electronic communication channels are becoming increasingly active in generating environmentally conscious online content with the intention of influencing mainstream opinion (Barber, Taylor, $\&$ Strick, 2009). Studies have sought to understand how social media works as an interactive channel for consumers who subscribe to environmentalist ideology and try to effect social change (Luck \& Ginanti, 2013). Research has found that User-Generated Content, (UGC), can reflect and impact on tourists" perceptions and attitudes towards "green" or "eco" activities. 
For example, Kane, Chiru, and Ciuchete (2012) found that Facebook represents an innovative channel that could build the necessary links between tourists' green values and behavioral change. Batat and Prentovic (2014) explored and compared the way social media is used in promoting responsible travel behavior and sustainable actions in three cultural contexts. Hardeman, Font, and Nawijn (2017) found that the online messages were more persuasive than those provided by tour operators. However, our understanding of social media's impact on sustainable tourism is still in its infancy, especially in terms of pro-environmental behavioral intention. Although it is widely accepted that norms play a dominant role in pro-environmental tourist behavior (e.g. Doran, Hanss \& Larsen, 2017), it is unclear whether new interactive communication channels can effectively activate these norms.

Focusing on a Chinese context, this study aims to investigate the effectiveness of proenvironmental travel UGC in activating pro-environmental tourist norms. The number of Chinese tourists is increasing consistently, as a result of economic development and an increased number of national holidays, reaching 36.2 billion trips in 2013 (Jia \& Lin, 2015). Travel platforms such as "Ctrip.com" and "Qyer.com", are frequently used by Chinese tourists as they provide both travel services and opportunities for real-time conversations on travel communities. These online travel communities enable tourists to search for information, upload their travel experiences and make friends (Li, Zhang, Mao, \& Deng, 2011). Chinese people do not share the same concept of nature as Western culture, which has been explained as "the contrast between Confucianist and Western thought" (Aoyagi-Usui, Vinken, \& Kuribayashi, 2003, p. 24). By investigating how online environmental dialogues impact on Chinese tourists' environmental behaviour by activating their norms, the findings of this study will contribute to knowledge about tourism practices in this important market. The study also contributes to the study and understanding of consumer behavior in tourism by applying norm activation theory which can be transferred to a wide range of other contexts and which potentially offers an alternative to Theory of Planner Behavior in understanding links between attitudes and behavior.

\section{Theoretical background and research hypotheses}

\subsection{Norms and pro-environmental behavioral intentions}

Pro-environmental tourists can be defined as those "...who strive to reduce environmental impacts, contribute to environmental preservation and/or conservation efforts, and not disturb 
the ecosystem and biosphere of a destination during recreation/tourism activities" (Lee, Jan, \& Yang, 2013, p. 455). This definition reflects their environmental knowledge, concern and commitment that leads to particular kinds of decisions and actions. However, some researchers have noted that whilst tourists often express concerns towards environmental issues and indicate their willingness to act to protect the environment, this does not usually coincide with their actual behavior, which can be less environmentally friendly than stated attitudes (Harris, 2006). Tourists often feel disempowered and/or unwilling to change travel behavior due to a lack of awareness of options available, or because they do not wish to make sacrifices on holidays (Miller, Rathouse, Scarles, Holmes \& Tribe, 2010; Juvan \& Dolnicar, 2014).

In order to understand consumer behavior change, researchers have developed a variety of theoretical models and frameworks, of which Ajzen and Fishbein's (1980) model of Theory of Reasoned Action and Theory of Planned behavior (Ajzen, 1985, 1991) are the most influential. However, research has generally focused exclusively on the links between attitudes and behavior, which has overlooked the role of social situational factors, or norms, in the theory. Azjen and Fishbein argued that attitudes only influence behavior indirectly by influencing behavioral intentions, and that intentions are not only influenced by attitudes but also by social pressures. Therefore, the ultimate determinants of behavior are "the behavioral beliefs concerning its consequences" and "normative beliefs concerning the prescriptions of others" (Ajzen \& Fishbein, 1980, p. 239).

In pro-environmental behavior research, Norm Activation Theory has been found to be a more useful route to understanding and predicting actual behavior, than attitudes and intentions (Schwartz, 1977; De Groot \& Steg, 2009; Steg, Dreijerink, \& Abrahamse, 2005; Steg \& Groot, 2010). This is because Norm Activation Theory looks beyond surface attitudes to focus on awareness and responsibility (De Groot \& Steg, 2009). Focusing on personal norms, the theory has explained and predicted pro-environmental behavior successfully in a range of empirical contexts (Zhang, Zhang, Zhang, \& Cheng, 2014; Bamberg \& Moser, 2007; Mehmetoglu, 2010; Sandve \& Oggard, 2014). Norm Activation Theory has also been applied to the tourism context where personal norms were used to predict tourists' pro-environmental buying, recycling and travel mode choice (Antimova, Nawijn, \& Peeters, 2012).

Norms refer to "self-instructions to do what is perceived to be correct by members of a culture" (Solomon \& Harford, 1984, p. 460). In the pro-environmental behavior context, scholars generally make the distinction between personal and social norms. Personal norms are defined 
as "obligations that are enforced through an internalized sense of duty to act and guilt or related emotions for failure to act" (Vandenbergh, 2005, p. 1104). These norms have successfully predicted low-cost environmental behaviors and good intentions, including political behavior (Gärling, Fujii, Gärling, \& Jakobsson, 2003), environmental citizenship (Stern, 2000) and policy acceptability (De Groot \& Steg, 2009; Steg \& Uneken, 2004). In recent tourism research, personal norms were supported as a stronger predictor of pro-environmental behavior than other psychological variables, or socio-demographic characteristics (Doran, Hanss \& Larsen, 2017).

Schwartz (1977) suggests that the relationship between personal norms and human behavior depends on how individuals define an action situation. He further identified two conditions that must exist before individuals identify situations under which personal norms will be "activated". First, individuals must have awareness that their activities may impact the welfare of others. Second, individuals must accept some responsibility for their activities and their impacts (Schwartz, 1977). Although this theory has been applied as a moderator model in a few studies, it is widely argued that the norm-activation model should be best interpreted as a mediator model (e.g. De Groot \& Steg 2009; Chiu, Lee, \& Chen, 2014; Zhang, 2014). This means it is more useful when conceptualized that an awareness of the consequences of one's behavior leads to a feeling of responsibility to engage in a modified way.

In this study, an awareness of consequences refers to tourists' pro-environmental awareness and the ascription of responsibility refers to tourists' pro-environmental responsibility. Although Norm Activity Theory links personal norms directly with behavior, a large body of literature has built up questioning the gap between intentions and actual behavior (Sheeran, 2002; Lee, Jan \& Yang, 2014; Cohen, Prayag \& Moital, 2014), and therefore personal norms, as perceived as responsibility and obligation, could lead to behavioral intentions, not as a predictor of actual behavior. A range of studies have found support for the theory that moral norms are a strong predictor of pro-environmental intentions (Bamberg \& Moser, 2007). Specifically focusing on sustainable travel choice, Kiatkawsin and Han (2017) found that personal norms and expectancy together can explain $48.3 \%$ of the variance on the behavioral intention. Therefore, the above discussion leads to the following hypotheses.

H1: Pro-environmental personal norms have an effect on tourists' pro-environmental behavioral intentions.

H2: Environmental awareness has an effect on tourists' environmental responsibility. 
H3: Environmental responsibility has an effect on tourists' pro-environmental personal norms.

\section{Social Norms}

As mentioned earlier, alongside personal norms, social determinants can also significantly impact on behavior, including social norms. Social norms are defined as "rules and standards that are understood by members of a group, and that guide and constrain social behavior without the force of laws" (Cialdini \& Trost, 1998, p. 152). According to the Focus Theory of Normative Conduct, individuals can enact behavior because they believe people that are important to them expect them to do so (descriptive subjective norms) or because failure to do so will lead to social sanctions (injunctive norms) (Cialdini, Reno, \& Kallgren, 1990). Previous studies support the contention that social norms can predict a variety of pro-environmental behavioral intentions, including intentions leading towards recycling behavior (Thomas \& Sharp, 2013), green consumption (Peattie, 2010), consumption reduction (Schultz, 2007) and eco decision making (Kane, Chiru \& Ciuchete, 2012). In the tourism context, Han's (2015) study also supports a direct positive relationship between tourists' pro-environmental social norms and their choice of green lodging. Doran, Hanss and Larsen (2016) also found a positive relationship between social norms and eco-friendly travel choice. However, to date, there are no studies which have investigated the joint effects of personal and social norms on proenvironmental behavior.

Tourists' knowledge and awareness about environmental problems are likely significant cognitive preconditions for developing both injunctive and descriptive social norms (Turaga, Howarth \& Borsuk, 2010). In addition, feelings of responsibility towards the environment may also be a significant process contributing to the development of pro-environmental social norms (Turaga, Howarth, \& Borsuk, 2010). The sense of responsibility for a harmful behavior usually triggers emotional reactions, namely guilt (Weiner, 2000). Feelings of guilt may not only result in a sense of obligation (personal norms), but also lead to a perceived mismatch between social norms and individual behavior (Turaga, Howarth, \& Borsuk, 2010). Hence, both environmental awareness and environmental responsibility are proposed as antecedents of pro-environmental social norms.

H4: Pro-environmental social norms have an effect on tourists' pro-environmental behavioral intentions. 
H5: Pro-environmental awareness has an effect on tourists' pro-environmental social norms.

H6: Pro-environmental responsibility has an effect on tourists' pro-environmental social norms.

\section{Pro-environmental UGC engagement}

Currently the Internet is an expanding network, which is used by an increasing number of people for various purposes, generating a large quantity of User Generated Content (UCG). Various online virtual communities have been established to stimulate individual's sustainable behavior (Langley \& van den Broek, 2010). These virtual communities have generated a large quantity of environmental discussion. We define these environmental dialogues generated by the users of tourism social media as pro-environmental travel UGC. This pro-environmental UGC often contain persuasive communication, which aims at influencing attitudes and behaviors by delivering information through both the core and peripheral routes. Previous studies show how effective social media can be at promoting an agenda for sustainable consumption practices and lifestyles (Luck \& Ginanti, 2013). Specifically, focusing on an online travel community, Rokka and Monsanda (2009) highlighted the important role that online environmental dialogue plays in setting the stage for collective cultural production.

In a social media context, users, rather than receiving messages from web pages passively, are positively engaged in online conversations to generate collective intelligence (Hvass \& Munar, 2012). By sharing travel experiences, exchanging information online and staying in touch with family and friends, travelers create what Bach and Stark (2004) refer to as incipient knowledge communities that are capable of restructuring interdependencies, and transforming relationships with the knowledge that is produced. UGC can persuade people by influencing their beliefs and attitudes, and ultimately their behavior (Spark, Perkins, \& Buckley, 2013; Batat \& Prentovic, 2014; Buhalis, 2002). As such we propose that the extent to which tourists engage in the pro-environmental UGC, impacts their pro-environmental personal norms.

H7: Pro-environmental travel UGC engagement enhances tourists' pro-environmental personal norms.

Links between social media and social norms can be found in the literature. For example, studies that investigate the social benefits brought about through online communication in the tourist sector demonstrate that tourists' active communication based on similar travel interests 
can increase a sense of in-group norms (Casaló, Flavián, \& Guinalíu, 2010; Feng \& Morrison, 2007; Xiang \& Gretzel, 2010). Social media can not only stimulate discussion between friends, family, colleagues and neighbors, but also with strangers, which is likely to influence people's perceived descriptive social norms and their expectations concerning the behavior (Xiang \& Gretzel, 2010). The unique sharing and communication features of social media applications allow users to see others' actions, which may stimulate them to take actions independently (Langley \& van den Broek, 2010). Social feedback can nudge people to adopt certain behaviors (Nigbur, Lyons, \& Uzzell, 2010). Sharing experiences gives active members recognition of their activities, which can be an incentive for other members to be active (Cummings, Butler, $\&$ Kraut, 2002). Therefore, we propose that pro-environmental UGC engagement significantly activates social norms.

H8: Pro-environmental travel UGC engagement enhances tourists' pro-environmental social norms.

A direct relationship between social media engagement and tourist behavioral intentions is also implied in the literature. Studies have shown that social media impacts on tourists' destination choice (Jacobsen \& Munar, 2012), hotel online booking (Ye, Law, Gu, \& Chen, 2011), and accommodation choice (Gretzel, Kang, \& Lee, 2008). In terms of pro-social behavior, Kane, Chiru, and Ciuchetes (2012) also found that Facebook represents a creative and innovative environment that could enhance green behavioral intentions. In a more recent study, Hardman, Font, and Nawijn (2017) found that messages with a clear focus on social and personal norms could impact holiday-makers' preference towards opting for sustainability actions. Therefore, we assume social media engagement can impact on pro-environmental behavioral intentions.

H9: Pro-environmental travel UGC engagement enhances tourists' pro-environmental behavioral intentions.

Additionally, the relationships between awareness, responsibility and pro-environmental travel UGC engagement need to be researched. Firstly, most studies imply prior knowledge encourages external information search because this facilitates the processing of new information (Rao \& Sieben, 1992; Gursoy, 2004). Tourists having pro-environmental awareness may formulate more questions, thereby leading them to search online (Gursoy, 2004). Sparks, Perkins, \& Buckley (2013) found for example that consumers with environmental concerns seemed to pay attention to social and environmental content on social media websites. Therefore, we argue that environmental awareness is antecedent to pro- 
environmental travel UGC engagement. On the other hand, social media has been found to be able to stimulate people's participation in pro-environmental initiatives, and has an ultimate linkage with their feelings of empowerment (Langley \& van den Broek, 2010; Garrett, 2006; Qu \& Lee, 2011). Therefore, we assume that people with environmental responsibility may positively engage in generating pro-environmental UGC.

H10: Environmental awareness encourages tourists to actively engage in pro-environmental travel $U G C$.

H11: Tourists with environmental responsibility actively engage in pro-environmental UGC.

Figure 1 outlines the hypothesized model based on these conceptual discussions. Generally we propose that tourist's pro-environmental social norms, personal norms and pro-environmental travel UGC engagement directly affects tourists' pro-environmental behavioral intentions. Environmental awareness and environmental responsibility are two antecedents of personal norms, pro-environmental travel UGC engagement and social norms.

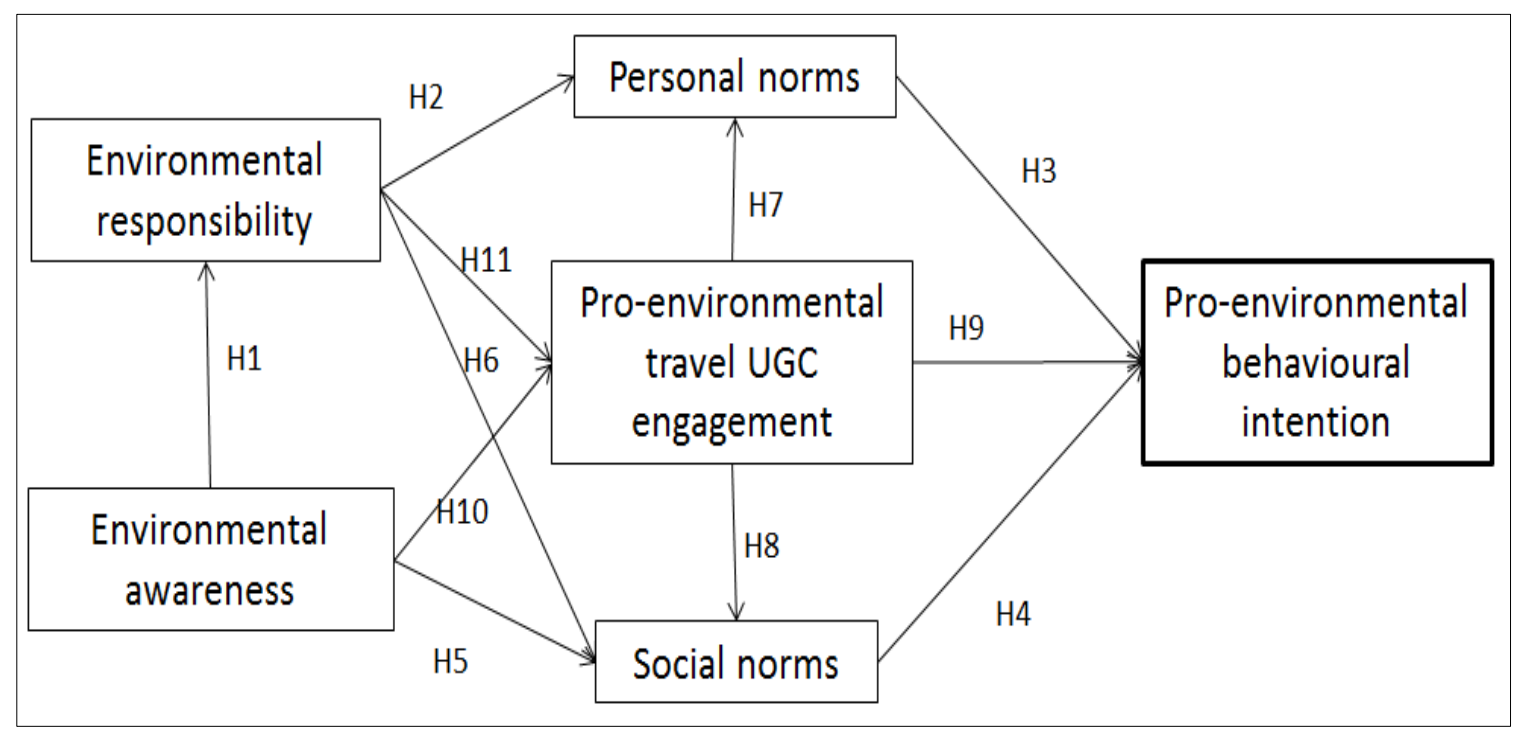

Fig.1 Hypothesized model

\section{Methodology}

\subsection{Data Collection and Sampling}

A survey questionnaire was developed to test the proposed conceptual model. All the measurements used by this study were referenced from the tourism and psychology literature. The items were measured with a seven-point Likert-type scale ranging from strongly disagree 
(1) to strongly agree (7). The initial version of the questionnaire was reviewed by an expert panel of three scholars and pre-tested. Based on feedback received, minor adjustments were made. All the items were scrutinized by the panel. They were asked to rate each scale and provide suggestions for applicable alternatives. To make the final selection of measurement items, we conducted a pilot study with a sample of 125 Chinese tourists in August 2015, which provided initial support for the hypotheses and the measures. Originally, the methodological model was to test influences on pro-environmental behavior, as Norm Activation Theory has previously been applied to predict pro-environmental behavior. Additionally, the original questionnaire utilized a 5-point Likert scale. 823 questionnaires were collected during September 2016 to January 2017, and the results analyzed. Yet in the light of criticisms of a 5point scale and concerns about the ability to predict actual behavior, the hypotheses and model were revised, and a new set of questionnaires developed using a 7-point scale, which were distributed between May and July 2017. The questionnaire and its source literature can be found in the Supplemental Data section of the web-based version of this paper.

This study targeted individuals with social media access and who travel on a regular basis. The web platform Wenjuan.com was used to collect data. Wenjuan.com is currently the biggest free web survey platform in China. The survey was developed in English and translated into Chinese. One screening question about travel frequency helped the authors target people who had travelled at least once within the 12 months before the survey. This approach was taken to try to minimize the potential for social desirability bias given that a researcher was not present to conduct survey interviews. The survey pages first introduced the main purpose of this study, and then participants were directed to popular Chinese travel websites to gain an understanding of the meaning of pro-environmental UGC. Within 2 months of launch, the survey was terminated with 1087 Chinese people who accessed the link to the survey. After excluding unusable responses and outliers, 1043 responses met the requirements of this study and were retained for data analysis. We firstly compared the results with those generated from the first set (using the 5-point scale and measuring the relationships between norms and proenvironmental behavior), and found that the results were similar and both models supported. Whilst we do not explicitly seek to compare the validity of measures and the models, we argue that this first set of data gives stronger support to the hypotheses and validation of the measurements.

Table 1 outlines the profile of the respondents. Among the 1043 respondents, 581 were females and 462 were males. Most (82.2\%) of the respondents were aged between 18-34 and $53.9 \%$ of 
the respondents had a college/university degree. All the respondents reported that they travel at least once every year. Also, all of them reported they had visited one travel website at least once, with the majority having used popular online travel communities including, "Ctrip.com" and "Qyer.com". "Ctrip.com" was the most frequently visited website by the respondents (39.1\%). This sample represents the typical demographic profile of users of online communities in China. The younger generation is the most technologically articulate group in China and more skillful at using computers than other groups. Specifically, compared to high school students, college/university students have more control over their time and actual use of computing technology so they are able to spend more time on social media (Lu, Zhou, \& Wang, 2009).

\begin{tabular}{|c|c|c|}
\hline Profiles & & Percentage \\
\hline \multirow[t]{3}{*}{ Gender } & & \\
\hline & M & $48.7 \%$ \\
\hline & F & $51.3 \%$ \\
\hline \multirow[t]{7}{*}{ Age } & & \\
\hline & $18-24$ & $10.3 \%$ \\
\hline & $25-34$ & $37.9 \%$ \\
\hline & $35-44$ & $28.3 \%$ \\
\hline & $45-54$ & $14.9 \%$ \\
\hline & 55-64 & $5.7 \%$ \\
\hline & More than 65 & $2.9 \%$ \\
\hline \multirow[t]{3}{*}{ Education } & & \\
\hline & $\begin{array}{c}\text { Primary school or } \\
\text { under }\end{array}$ & $0.9 \%$ \\
\hline & Middle School & $8.8 \%$ \\
\hline
\end{tabular}




\begin{tabular}{|c|c|c|}
\hline & $\begin{array}{c}\text { High } \\
\text { School/Vocational } \\
\text { School }\end{array}$ & $23.7 \%$ \\
\hline & College/University & $53.9 \%$ \\
\hline & Master or Ph.D. & $12.7 \%$ \\
\hline \multirow[t]{4}{*}{ Travel frequency(times/year) } & 1 & $32.6 \%$ \\
\hline & $2--3$ & $54.2 \%$ \\
\hline & $4--10$ & $10.1 \%$ \\
\hline & More than 10 & $3.1 \%$ \\
\hline \multirow[t]{4}{*}{ The most frequently visited travel website } & Qunar.com & $30.7 \%$ \\
\hline & Qyer.com & $15.9 \%$ \\
\hline & Ctrip.com & $39.1 \%$ \\
\hline & Others & $14.3 \%$ \\
\hline
\end{tabular}

Table.1 Participant profile

\subsection{Measurement validity and reliability}

The validity and reliability of the measurements was tested in a Structural Equation Model (SEM). SEM assumes two contrasting types of measurement: reflective and formative constructs. Reflective indicators imply a construct where the observable items are chosen and measured as they are the reflection of the prior theoretical latent construct (deductive reasoning), whereas formative indicators are inferred from the configuration of the observed variables (inductive reasoning) (Baumann, Elliott, \& Hamin, 2011). In this case, all constructs were reflective. The Cronbach's Alpha is widely used to test the internal consistency within a construct, and thus the reliability of the results. The Cronbach's Alphas for all the constructs ranged from 0.807 to 0.927 , which is generally considered acceptable (Santos, 1999). 
Subsequently, we used Composite Reliability measures to test for internal consistency because this is recommended for Partial Least Squares (PLS) path models, since the Cronbach's Alpha focuses on the internal reliability of latent variables (Henseler, Ringle, \& Sinkovics, 2009). The CR tests achieved a range from 0.886 to 0.945 , which meets the stipulated thresholds. The factor loadings of all the items were greater than 0.7 and significant $(\mathrm{p}<0.01)$, indicating an acceptable level of internal validity (Cheng, Lam, \& Yeung, 2006). Therefore, the measurement model suggests that all the constructs have a high level of internal consistency.

The average variance extracted (AVE) was used to analyze the convergent validity. Researchers have shown good convergent validity if AVE values are 0.5 and higher, which represents at least half of an indicator's variance (Bagozzi \& Yi, 1988). Table 2 shows that AVE values were all above 0.7 , indicating a good degree of convergent validity. For discriminant validity, a latent construct should share more variance with its assigned indicators than with any other latent constructs (Fornell \& Larcker, 1981). Each construct met this requirement, showing a satisfactory level of discriminant validity (table 3). Also, the analysis estimated the cross loadings and each indicator's loadings were greater than all of its cross loadings. Therefore, the model has a high degree of discriminant validity.

\begin{tabular}{|c|c|c|c|c|c|}
\hline Constructs & Items & $\begin{array}{c}\text { Factor } \\
\text { loading }\end{array}$ & $\begin{array}{c}\text { Crobach's } \\
\text { Alpha }\end{array}$ & AVE (0.5) & $\begin{array}{c}\text { Composite } \\
\text { Reliability }\end{array}$ \\
\hline PN & 4 & $0.853-0.903$ & 0.904 & 0.776 & 0.8933 \\
\hline SN & 4 & $0.877-0.903$ & 0.912 & 0.792 & 0.938 \\
\hline INTENTION & 5 & $0.851-0.916$ & 0.927 & 0.776 & 0.945 \\
\hline AWARNESS & 4 & $0.882-0.900$ & 0.911 & 0.788 & 0.937 \\
\hline RESPONSIBLITY & 4 & $0.784-0.883$ & 0.807 & 0.721 & 0.886 \\
\hline UGC ENGAGEMENT & 4 & $0.840-0.904$ & 0.896 & 0.763 & 0.928 \\
\hline
\end{tabular}

Table.2 Reliability and validity tests

\begin{tabular}{|c|c|c|c|c|c|c|}
\hline Construct & AWARENESS & RESPONSIBLITY & INTENTION & PN & SN & UGC ENGAGEMENT \\
\hline AWARENESS & 0.888 & & & & & \\
\hline
\end{tabular}




\begin{tabular}{|c|c|c|c|c|c|c|}
\hline RESPONSIBLITY & 0.526 & $\mathbf{0 . 8 4 9}$ & & & \\
\hline INTENTION & 0.515 & 0.828 & $\mathbf{0 . 8 8 1}$ & & & \\
\hline PN & 0.489 & 0.542 & 0.510 & $\mathbf{0 . 8 8 1}$ & & \\
\hline SN & 0.515 & 0.566 & 0.541 & 0.499 & $\mathbf{0 . 8 9 0}$ & \\
\hline UGC ENGAGEMENT & 0.473 & 0.731 & 0.524 & 0.466 & 0.489 & $\mathbf{0 . 8 7 3}$ \\
\hline
\end{tabular}

Table. 3 Discriminant validity test

\subsection{Data analysis}

The data were analyzed using Smartpls 3.0 software. SEM evaluates both the assumed relationships among dependent and independent variables (structural model) and the loadings of the observed measurement constructs on their expected latent variables (measurement model), which makes it is possible to understand whether measurement errors in the observed variables are an integral aspect of the model (Ayeh, Au, \& Law, 2013). PLS is a soft modelling approach to SEM, which does not consider data distribution (Wong, 2013). It is especially suitable for the circumstances when sample sizes are small, or where the aim is to develop theory and where predictive accuracy is paramount (Henseler, Ringle, \& Sinkovics, 2009). This study aimed to explore the role of social media on tourists' pro-environmental norms and behavioral intentions, thus a PLS model was appropriate as the preferred method when trying to develop theories (Hair, Ringle, \& Sarstedt, 2011).

According to the guidance suggested by Marcoulides and Saunders (2006), the minimum sample size required for this study would be 88 because the model contains nine arrows directed to a latent variable. Obviously, our sample of 1043 meets the minimum requirement for conducting SEM analysis (Hair, 2010). Furthermore, this sample size is sufficient to test the mediating effects since the median sample size used to test for this in previous studies was 187 (Fritz \& MacKinnon, 2007).

\section{Results}


The analysis tested the explanatory and predictive power of the proposed model, the size of the path coefficients and the significance of the hypothesized relationships. In the PLS algorithm, the variance explained $\left(\mathrm{R}^{2}\right)$ was used to evaluate the structural model. $\mathrm{R}^{2}$ values of $0.19,0.33$ and 0.67 for endogenous latent constructs of the structural model represent the weak, moderate or substantial support for the relationships of the structural model (Chin, 1998). As shown in table 4 , the model could explain $30.4 \%$ of the variance on pro-environmental personal norms, $39.1 \%$ of the variance in pro-environmental social norms and $42.1 \%$ of the variance in proenvironmental behavioral intentions. Hence, the proposed model is sufficient to reflect tourists' pro-environmental norms and behavioral intentions. $\mathrm{R}^{2}$ values for pro-environmental UGC engagement were 0.546 , indicating that the model does reflect tourists' pro-environmental UGC engagement. Gesser's $\mathrm{Q}^{2}$ test was used to test the model's ability to predict, which has been widely used to assess the predictive validity of the exogenous latent variables. $\mathrm{Q}^{2}$ values greater than zero suggests the exogenous constructs have predictive relevance for the endogenous constructs (Chin, 1998). As shown in table 4, all $\mathrm{Q}^{2}$ values were above zero, which indicates high predictive power of all exogenous constructs.

\begin{tabular}{|c|c|c|}
\hline Constructs & $\mathbf{R}^{\mathbf{2}}$ & $\mathbf{Q}^{\mathbf{2}}$ \\
\hline PN & 0.304 & 0.222 \\
\hline SN & 0.391 & 0.291 \\
\hline INTENTION & 0.421 & 0.305 \\
\hline RESPONSIBLITY & 0.277 & 0.188 \\
\hline UGC ENGAGEMENT & 0.546 & 0.391 \\
\hline
\end{tabular}

Table 4: $R^{2}$ values and $Q^{2}$ values

$\mathrm{T}$ values were calculated to test the path coefficients by bootstrapping. We used a nonparametric bootstrapping procedure to test 1043 cases, 5000 subsamples and individual sig changes (Hair, Ringle, \& Sarstedt, 2011). The results revealed that the hypothesized relationships in the inner path model exhibited statistically significant figures (see table 5). All hypothesizes were strongly supported since the $\mathrm{P}$ values were below 0.001 . This verifies the significant role of UGC in the model.

\begin{tabular}{|l|l|l|l|l|}
\hline Variables & Path coefficient & P Value & T Value & Hypotheses \\
\hline PN-INTENTION & 0.239 & $0.000^{* * *}$ & 9.786 & H1: Accepted \\
\hline RES-PN & 0.432 & $0.000^{* * *}$ & 13.836 & H2: Accepted \\
\hline
\end{tabular}




\begin{tabular}{|l|l|l|l|l|}
\hline AWR-RES & 0.526 & $0.000 * * *$ & 23.479 & H3: Accepted \\
\hline SN-INTENTION & 0.289 & $0.000 * * *$ & 11.975 & H4: Accepted \\
\hline AWR-SN & 0.288 & $0.000^{* * * *}$ & 11.533 & H5: Accepted \\
\hline RES-SN & 0.337 & $0.000^{* * * *}$ & 11.625 & H6: Accepted \\
\hline UGC-PN & 0.151 & $0.000^{* * * *}$ & 4,449 & H7: Accepted \\
\hline UGC-SN & 0.107 & $0.000 * * *$ & 3.803 & H8: Accepted \\
\hline UGC-INTNETION & 0.271 & $0.000^{* * * *}$ & 10.844 & H9: Accepted \\
\hline AWR-UGC & 0.122 & $0.000^{* * * *}$ & 5.924 & H10: Accepted \\
\hline RES-UGC & 0.667 & $0.000 * * *$ & 49.115 & H11: Accepted \\
\hline
\end{tabular}

Tab.5 Results of hypothesis testing (p<0.001***; $p<0.01 * * ; p<0.05 * ; p>0.05=N . S$.

Furthermore, we tested for the mediation effect of pro-environmental travel UGC engagement. Initially, we followed the approach of Baron and Kenny (1986) to test whether proenvironmental travel UGC engagement mediates the relationship between pro-environmental awareness, responsibility and pro-environmental behavioral intentions. Our results suggested that to be the case. Following that, we adopted the Sobel test values for mediation. The Sobel test is a statistical method to investigate the significance of the mediator in relation to the independent and dependent variables (Leigh \& Milgrom, 2008). The Sobel test $\mathrm{P}$ values for our data were 0.000 and 0.000 respectively, indicating that pro-environmental travel UGC engagement is a strong mediator between environmental awareness and pro-environmental behavioral intentions as well as between environmental responsibility and pro-environmental behavioral intentions.

\begin{tabular}{|l|ll|l|l|l|l|l|}
\hline Mediation effect & \multicolumn{2}{|l|}{ Variables } & P value & T value & $\begin{array}{l}\text { Sobel test } \\
\text { statistic }\end{array}$ & $\begin{array}{l}\text { Sobel test P } \\
\text { value }\end{array}$ & $\begin{array}{l}\text { Mediating } \\
\text { role }\end{array}$ \\
\hline AWR UGC & AWR & UGC & $0.000^{* * *}$ & 5.924 & 6.341 & $0.000^{* * * *}$ & Support \\
INTENTION & UGC INTENTION & $0.000^{* * *}$ & 10.844 \\
& AWR & INTENTION & $0.000^{* * *}$ & 5.828 & & & \\
\hline RES UGC & RES & UGC & $0000^{* * *}$ & 49.115 & 12.80 & $0.000^{* * * *}$ & Support \\
INTENTION & UGC INTENTION & $0.000^{* * *}$ & 10.844 & & & \\
& RES INTENTION & $0.000^{* * *}$ & 40.257 & & & \\
\hline
\end{tabular}

Tab. 6 Results of mediation test $(\mathbf{p}<0.001 * * * ; p<0.01 * * ; P<0.05 * ; p>0.05=N . S$. $)$ 
We then controlled for gender, age, education and income level since previous studies indicate that these factors may impact on people's pro-environmental intentions (Barr \& Silg, 2007). Two control variables were found to be significantly related, namely age and education. Young people tended to have stronger pro-environmental behavioral intentions and those who had higher education background also reported intentions towards greater environmental responsibility.

\section{Discussion and conclusion}

Firstly, this study found strong support for the relationships between the constructs which confirms previous studies on Norm Activation Theory and pro-environmental behavioral intentions. As such, tourists with more environmental awareness tend to bear a sense of responsibility and feel a greater moral obligation towards the environment, and thus are more likely to have the intention to act pro-environmentally in their tourism behavior. Our findings support the interpretation of Norm Activation Theory, of which awareness of consequences (AC) and ascription of responsibility (AR) are two preconditions of personal norm activation, and are best treated as mediators of personal norms (De Groot \& Steg, 2009; Han \& Hwang, 2016; Van Riper \& Kyle, 2014; Zhang, Zhang, Zhang, \& Cheng, 2014).

Additionally, we also provide further verification of the significant role of social norms in predicting pro-environmental tourist behavioral intentions, confirming recent studies (Antimova, Rawijn, \& Peeters, 2012; Han 2015). This study also supports the conceptualization that environmental awareness and environmental responsibility are antecedent to pro-environmental social norms. This indicates that people with more understanding about the consequences of their behavior in regard to the environment and who feel more responsibility for their behavior, tend to link their pro-environmental behavioral intention with social sanctions or approvals. Furthermore, these indicate that tourists with proenvironmental awareness and responsibility would generally believe that their reference group should bear the same sense of awareness and responsibility. These beliefs would lead to their expectations for collective action towards greater pro-environmental actions.

This research adds to the growing interest in ways to achieve behavioral change in tourists (Hall, 2016), and to the growing interest and debate about the relationship between sustainable tourism and marketing (Font \& McCabe, 2017). It is the first study to investigate the role of social media in activating pro-environmental norms amongst tourists. Although previous 
literature implies that social media is an effective instrument in promoting pro-environmental behavior, no literature has examined its role in activating pro-environmental norms. Our findings also support the important and significant role of pro-environmental UGC in promoting pro-environmental behavior, which has been proposed in previous studies (Langley \& van den Broek, 2010; Fischer \& Reuber, 2011). This implies that social media can be an effective communication channel to motivate pro-environmental behavioral intentions. Our findings show that pro-environmental UGC activates tourists' pro-environmental personal norms, providing empirical support to the argument of Vandenbergh (2005), that information can accelerate the process of personal norm activation, by making people aware of environmental issues and thus accepting their personal responsibility. Previous studies show that the activation of personal norms depends on the interplay of cognitive, emotional and social factors (Bierhoff, 2002). Further studies could focus on how to make online conversations target these factors to activate tourists' pro-environmental personal norms more effectively. In addition to personal norms, pro-environmental travel UGC engagement activates tourists' social norms, which is in accordance with the findings of Hardeman, Font, and Nawijn (2017) who found that messages focusing on personal and social norms could impact holiday makers' preferences towards opting for sustainability actions. UGC engagement not only provides information, but more importantly creates an online community. Therefore, the more tourists engage in pro-environmental UGC, the more likelihood they will be associated with pro-environmental social groups and to help spread this type of content amongst their own networks. Luo and Zhong (2015) explained that the impact of travel-related online communications depends on the existence of a social relationship. Foster and Lawson (2013) further argued that social media effectively activates pro-environmental social norms through their case study of Facebook. They found that people are able to effectively reduce household energy consumption through competition with their friends. Our study opens up the potential for further research on the role that online persuasive communication in social media channels can play in activating environmentally responsible attitudes, intentions and behaviors.

The findings further revealed that environmental awareness and environmental responsibility are two motivational factors for engaging in pro-environmental UGC, supporting the conclusions of Gursoy (2004) and Sparks, Perkins, and Buckley (2013). This implies that people with more concern about the environment and who feel greater personal responsibility, tend to actively participate in online communication channels. Gursoy (2004) found that tourists with pro-environmental awareness may formulate more questions and search more 
frequently online. Therefore, they may be assumed to have a higher level of UGC engagement. However, according to Dijck (2009), among all UGC users, only a small proportion are active, whereas more are "passive spectators" (33\%) and the majority "inactive" (52\%). Our findings show that when people perceive they have more responsibility for the environment they not only consume online pro-environmental information, but also actively generate UGC to influence pro-environmental intentions of others. Further work on the role of opinion leaders in pro-environmental UGC could help understand how content creators could extend their influence to a wider proportion of the online travel community.

A number of theoretical and practical implications arise. Conceptually, the research identified the importance of pro-environmental knowledge and pro-environmental responsibility because they not only activate people's pro-environmental norms, but also promote people's contribution to online environmental dialogue. This supports the conclusion that prior knowledge is an antecedent of social media engagement, and further identifies that responsibility is significant for individuals' activate participation in online discussion in proenvironmental issues. Therefore, our study implies that providing sufficient knowledge and engendering a sense of responsibility are effective methods of drawing public attention to environmental issues and guiding the direction of online discussion content.

Practically, this study provides implications for tourism management. By encouraging people to actively participate in tourism related social media to discuss environmental issues, proenvironmental travel UGC will be enriched, which will further activate tourists' environmental norms and increase their intentions to act more pro-environmentally. Besides the most frequently tested variables of values and attitudes, this study attests to the importance of proenvironmental norms as an additional tool for understanding how consumers can be influenced towards more pro-environmental actions.

The research findings imply that norms are useful in investigating pro-environmental intention, and could help in further studies of pro-environmental behavior. It suggests the need for further studies regarding social media impacts on pro-environmental behavior or intentions in tourism. Meanwhile, with the application of this study to the Chinese context, the study provides insights into this important emerging market, but also calls for further application in different cultural contexts to enable cross-cultural analysis in regard to pro-environmental tourist behavior. 


\section{References}

Ajzen, I. (1985). From intentions to actions: A theory of planned behavior. In J. Kuhl \& J. Beckmann (Eds.), Action-control: From cognition to behavior (pp. 11-39). Heidelberg: Springer.

Ajzen, I. (1991). The theory of planned behavior. Organizational Behavior And Human Decision Processes, 50(2), 179-211.

Ajzen, I., \& Fishbein, M. (1980). Understanding attitudes and predicting social behavior. Englewood Cliffs, NJ: Prentice-Hall.

Antimova, R., Nawijn, J., \& Peeters, P. (2012). The awareness/attitude-gap in sustainable tourism: a theoretical perspective. Tourism Review of AIEST - International Association of Scientific Experts in Tourism, 67(3), 7-16. doi:http://dx.doi.org/10.1108/16605371211259795

Aoyagi-Usui, M., Vinken, H., \& Kuribayashi, A. (2003). Pro-environmental attitudes and behaviors: An international comparison. Human Ecology Review, 10(1), 23-31.

Ayeh, J. K., Au, N., \& Law, R. (2013). Predicting the intention to use consumer-generated media for travel planning. Tourism Management, 35, 132-143.

Bach, J., \& Stark, D. (2004). Link, search, interact the co-evolution of NGOs and interactive technology. Theory, Culture \& Society, 21(3), 101-117.

Bagozzi, R. P., \& Yi, Y. (1988). On the evaluation of structural equation models. Journal Of The Academy Of Marketing Science, 16(1), 74-94.

Bamberg, S., Hunecke, M., \& Blöbaum, A. (2007). Social context, personal norms and the use of public transportation: Two field studies. Journal Of Environmental Psychology, 27(3), 190-203.

Barber, N., Taylor, C., \& Strick, S. (2009). Wine consumers' environmental knowledge and attitudes: Influence on willingness to purchase. International Journal of Wine Research, 1(1), 59-72.

Baron, R. M., \& Kenny, D. A. (1986). The moderator-mediator variable distinction in social psychological research: Conceptual, strategic, and statistical considerations. Journal of Personality and Social Psychology, 51(6), 1173-1182. 
Barr, S., \& Gilg, A. W. (2007). A conceptual framework for understanding and analyzing attitudes towards environmental behaviour. Geografiska Annaler Series B: Human Geography, 89(4), 361-379.

Batat, W., \& Prentovic, S. (2014). Towards viral systems thinking: a cross-cultural study of sustainable tourism ads. Kybernetes, 43(3/4), 529-546.

Baumann, C., Elliott, G., \& Hamin, H. (2011). Modelling customer loyalty in financial services: a hybrid of formative and reflective constructs. International Journal of Bank Marketing, 29(3), 247-267.

Bierhoff, H. W. (2002). Prosocial behaviour. Philadelphia, PA, Psychology Press.

Buckley, R. (2012). Sustainable tourism: Research and reality. Annals of Tourism Research, $39(2), 528-546$.

Buhalis, D., \& Licata, M. C. (2002). The future eTourism intermediaries. Tourism Management, 23(3), 207-220.

Casaló, L. V., Flavián, C., \& Guinalíu, M. (2010). Determinants of the intention to participate in firm-hosted online travel communities and effects on consumer behavioral intentions. Tourism Management, 31(6), 898-911.

Charter, M. (1992). Greener marketing: A responsible approach to business. Sheffield, UK. Greenleaf Publishing.

Cheng, T. C. E., Lam, D. Y. C., \& Yeung, A. C. L. (2006). Adoption of internet banking: an empirical study in Hong Kong. Decision Support Systems, 42(3), 1558-1572.

Chin, W. W. (1998). Commentary: Issues and opinion on structural equation modeling: MIS Quarterly, 22(1), vii-xvi.

Chiu, Y.-T. H., Lee, W.-I., \& Chen, T.-H. (2014). Environmentally responsible behavior in ecotourism: Antecedents and implications. Tourism Management, 40(0), 321-329.

Cialdini, R. B., Reno, R. R., \& Kallgren, C. A. (1990). A focus theory of normative conduct: recycling the concept of norms to reduce littering in public places. Journal of Personality and Social Psychology, 58(6), 1015-1026.

Cialdini, R. B., \& Trost, M. R. (1998). Social influence: Social norms, conformity and compliance. In: Gilbert D., Fiske S., Lindzey G. (eds) The Handbook of Social Psychology, 4th edition. New York, Oxford University Press.

Cohen, S. A., Prayag, G., \& Moital, M. (2014). Consumer behaviour in tourism: Concepts, influences and opportunities. Current Issues in Tourism, 17(10), 872-909.

Cummings, J. N., Butler, B., \& Kraut, R. (2002). The quality of online social relationships. Communications of the ACM, 45(7), 103-108. 
De Groot, J. I. M., \& Steg, L. (2009). Morality and Prosocial Behavior: The Role of Awareness, Responsibility, and Norms in the Norm Activation Model. Journal of Social Psychology, 149(4), 425-449.

Dijck, J. V. (2009). Users like you? Theorizing agency in user-generated content. Media, Culture and Society, 31(1), 41-58.

Doran, R., Hanss, D., \& Larsen, S. (2017). Intentions to make sustainable tourism choices: do value orientations, time perspective, and efficacy beliefs explain individual differences? Scandinavian Journal of Hospitality and Tourism, 17 (3), 223-238.

Feng, R., \& Morrison, A. M. (2007). Quality and value network marketing travel clubs. Annals of Tourism Research, 34(3), 588-609.

Fischer, E., \& Reuber, A. R. (2011). Social interaction via new social media:(How) can interactions on Twitter affect effectual thinking and behavior?. Journal of Business Venturing, 26(1), 1-18.

Font, X. \& McCabe, S. (2017) Sustainability and marketing in tourism: its contexts, paradoxes, approaches, challenges and potential, Journal of Sustainable Tourism, 25(7), 869-883

Fornell, C., \& Larcker, D. F. (1981). Structural equation models with unobservable variables and measurement error: Algebra and statistics. Journal of Marketing Research, 39(2), 382-388.

Foster, D., \& Lawson, S. (2013). 'Liking'persuasion: case studies in social media for behaviour change. Paper presented at the ACM SIGCHI Conference on Human Factors in Computing Systems, Paris, France. $27^{\text {th }}$ April $-2^{\text {nd }}$ May. Retrieved $17^{\text {th }}$ August, 2017 from https://noreenkamal.files.wordpress.com/2013/03/21-liking-persuasion-v1-df.pdf

Fritz, M. S., \& MacKinnon, D. P. (2007). Required sample size to detect the mediated effect. Psychological science, 18(3), 233-239.

Gärling, T., Fujii, S., Gärling, A., \& Jakobsson, C. (2003). Moderating effects of social value orientation on determinants of proenvironmental behavior intention. Journal of Environmental Psychology, 23(1), 1-9.

Garrett, R. K. (2009). Politically motivated reinforcement seeking: Reframing the selective exposure debate. Journal of Communication, 59(4), 676-699.

Gretzel, U., Kang, M., \& Lee, W. (2008). Differences in Consumer-Generated Media Adoption and Use: A Cross-National Perspective. Journal of Hospitality \& Leisure Marketing, $17,99-120$.

Gursoy, D., \& McCleary, K. W. (2004). An Integrative Model Of Tourists' Information Search Behavior. Annals of Tourism Research, 31(2), 353-373. 
Hair, J. F. (2010). Multivariate data analysis: A Global Perspective. Upper Saddle River, N.J., Pearson.

Hair, J. F., Ringle, C. M., \& Sarstedt, M. (2011). PLS-SEM: Indeed a silver bullet. Journal of Marketing Theory And Practice, 19(2), 139-152.

Hall, C.M. (2016) Intervening in academic interventions: framing social marketing's potential for successful sustainable tourism behavioural change, Journal of Sustainable Tourism, 24(3), 350-375,

Han, H. (2015). Travelers' pro-environmental behavior in a green lodging context: Converging value-belief-norm theory and the theory of planned behavior. Tourism Management, 47(0), 164-177.

Han, H., \& Hwang, J. (2016). Cruise travelers' environmentally responsible decision-making: An integrative framework of goal-directed behavior and norm activation process. International Journal of Hospitality Management, 53, 94-105.

Hardeman, G., Font, X., \& Nawijn, J. (2017). The power of persuasive communication to influence sustainable holiday choices: Appealing to self-benefits and norms. Tourism Management, 59, 484-493.

Hargreaves, T. (2011). Practice-ing behaviour change: Applying social practice theory to proenvironmental behaviour change. Journal of Consumer Culture, 11(1), 79-99.

Harland, P., Staats, H., \& Wilke, H. A. M. (2007). Situational and Personality Factors as Direct or Personal Norm Mediated Predictors of Pro-environmental Behavior: Questions Derived From Norm-activation Theory. Basic \& Applied Social Psychology, 29(4), 323-334.

Harris, P. G. (2006). Environmental Perspectives and Behavior in China Synopsis and Bibliography. Environment and Behavior, 38(1), 5-21.

Henseler, J., Ringle, C. M., \& Sinkovics, R. R. (2009). The use of partial least squares path modeling in international marketing. Advances In International Marketing, 20(1), 277319.

Hvass, K. A., \& Munar, A. M. (2012). The takeoff of social media in tourism. Journal of Vacation Marketing, 18(2), 93-103.

Jacobsen, J. K. S., \& Munar, A. M. (2012). Tourist information search and destination choice in a digital age. Tourism Management Perspectives, 1, 39-47.

Jia, Y.-j., \& Lin, D.-r. (2015). Influence Factors and Effects of Tourists' Environmentally Responsible Behaviors Based on Place Theory. China Population, Resources and Environment, 7, 022. 
Juvan, E., \& Dolnicar, S. (2014). The attitude-behaviour gap in sustainable tourism. Annals of Tourism Research 48, 76-95

Kane, K., Chiru, C., \& Ciuchete, S. G. (2012). Exploring the eco-attitudes and buying behaviour of Facebook users. Amfiteatru Economic, XIV(31), 157-171.

Kiatkawsin, K. \& Han, H. (2017). Young travelers' intention to behave pro-environmentally: Merging the value-belief-norm theory and the expectancy theory. Tourism Management, 59, 76-88.

Klöckner, C. A., \& Blöbaum, A. (2010). A comprehensive action determination model: Toward a broader understanding of ecological behaviour using the example of travel mode choice. Journal of Environmental Psychology, 30(4), 574-586.

Kollmuss, A., \& Agyeman, J. (2002). Mind the gap: why do people act environmentally and what are the barriers to pro-environmental behavior? Environmental Education Research, 8(3), 239-260.

Langley, D., \& van den Broek, T. (2010). Exploring social media as a driver of sustainable behaviour: case analysis and policy implications. Proceedings of the Internet Politics and Policy Conference. 16-17 $7^{\text {th }}$ September, Oxford. Retrieved $17^{\text {th }}$ August, 2017 from: http://ipp.oii.ox.ac.uk/sites/ipp/files/documents/IPP2010_Langley_vandenBroek_Pape r.pdf

Lee, T. H., Jan, F. H., \& Yang, C. C. (2013). Conceptualizing and measuring environmentally responsible behaviors from the perspective of community-based tourists. Tourism Management, 36, 454-468.

Leigh, B., \& Milgrom, J. (2008). Risk factors for antenatal depression, postnatal depression and parenting stress. BMC Psychiatry, 8(1), 24.

Li, M., Zhang, H., Mao, I., \& Deng, C. (2011). Segmenting Chinese outbound tourists by perceived constraints. Journal of Travel \& Tourism Marketing, 28(6), 629-643.

Lim, J. S., Hwang, Y., Kim, S., \& Biocca, F. A. (2015). How social media engagement leads to sports channel loyalty: Mediating roles of social presence and channel commitment. Computers in Human Behavior, 46, 158-167.

Lu, Y., Zhou, T., \& Wang, B. (2009). Exploring Chinese users' acceptance of instant messaging using the theory of planned behavior, the technology acceptance model, and the flow theory. Computers in Human Behavior, 25(1), 29-39.

Luck, E., \& Ginanti, A. (2013). Online environmental citizenship: Blogs, green marketing and consumer sentiment in the 21st Century. Electronic Green Journal, 1(35), 1-26. 
Luo, Q., \& Zhong, D. (2015). Using social network analysis to explain communication characteristics of travel-related electronic word-of-mouth on social networking sites. Tourism Management, 46(0), 274-282.

March, R., \& Woodside, A. G. (2005). Testing theory of planned versus realized tourism behavior. Annals Of Tourism Research, 32(4), 905-924.

Marcoulides, G. A., \& Saunders, C. (2006). Editor's comments: PLS: a silver bullet? MIS Quarterly, iii-ix.

Mehmetoglu, M. (2010). Factors Influencing the Willingness to Behave Environmentally Friendly at Home and Holiday Settings. Scandinavian Journal of Hospitality and Tourism, 10(4), 430-447

Miller, G., Rathouse, K., Scarles, C., Holmes, K., \& Tribe, J. (2010). Public understanding of sustainable tourism. Annals of Tourism Research, 37(3), 627-645.

Narangajavana, Y., Fiol, L. J. C., Tena, M. Á. M., Artola, R. M. R., \& García, J. S. (2017). The influence of social media in creating expectations. An empirical study for a tourist destination. Annals of Tourism Research, 65, 60-70.

Nigbur, D., Lyons, E., \& Uzzell, D. (2010). Attitudes, norms, identity and environmental behaviour: Using an expanded theory of planned behaviour to predict participation in a kerbside recycling programme. British Journal of Social Psychology, 49(2), 259-284.

Peattie, K. (2010). Green Consumption: Behavior and Norms. Annual Review of Environment and Resources, 35(1), 195-228.

Qu, H., \& Lee, H. (2011). Travelers' social identification and membership behaviors in online travel community. Tourism Management, 32(6), 1262-1270.

Ramkissoon, H., Smith, L. D. G., \& Weiler, B. (2013). Relationships between place attachment, place satisfaction and pro-environmental behaviour in an Australian national park. Journal of Sustainable Tourism, 21(3), 434-457.

Rao, A. R., \& Sieben, W. A. (1992). The effect of prior knowledge on price acceptability and the type of information examined. Journal of Consumer Research, 19(2), 256-270.

Sandve, A., \& Øgaard, T. (2014). Exploring the interaction between perceived ethical obligation and subjective norms, and their influence on CSR-related choices. Tourism Management, 42, 177-180.

Santos, J. R. A. (1999). Cronbach's alpha: A tool for assessing the reliability of scales. Journal of Extension, 37(2), 1-5. 
Schultz, P. W., Nolan, J. M., Cialdini, R. B., Goldstein, N. J., \& Griskevicius, V. (2007). The constructive, destructive, and reconstructive power of social norms. Psychological Science, 18(5), 429-434.

Schwartz, S. H. (1977). Normative Influences on Altruism1. Advances In Experimental Social Psychology, 10, 221-279.

Sheeran, P. (2002). Intention-behavior relations: A conceptual and empirical review. European review of social psychology, 12(1), 1-36.

Solomon, S. D., \& Harford, T. C. (1984). Drinking norms versus drinking behavior. Alcoholism: Clinical and experimental research, 8(5), 460-466.

Sparks, B. A., Perkins, H. E., \& Buckley, R. (2013). Online travel reviews as persuasive communication: The effects of content type, source, and certification logos on consumer behavior. Tourism Management, 39, 1-9.

Steg, L., Dreijerink, L., \& Abrahamse, W. (2005). Factors influencing the acceptability of energy policies: A test of VBN theory. Journal of Environmental Psychology, 25(4), 415-425.

Steg, L., \& Groot, J. (2010). Explaining prosocial intentions: Testing causal relationships in the norm activation model. British Journal Of Social Psychology, 49(4), 725-743.

Steg, L., \& Uneken, E. (2004). Car use: lust and must. Traffic and Transport Psychology: Theory and Application. Amsterdam: Elsevier, 443-452.

Stern, P. (2000). Toward a coherent theory of environmentally significant behavior. Journal of Social Issues, 56(3), 407-424.

Tapon, F., \& Leighton, T. (1991). Green as strategy: Lessons from the chemical industry. Cahiers de Recherche No. 1991-17, Guelph, Department of Economics, University of Guelph

Thomas, C., \& Sharp, V. (2013). Understanding the normalisation of recycling behaviour and its implications for other pro-environmental behaviours: A review of social norms and recycling. Resources, Conservation and Recycling, 79(0), 11-20.

Turaga, R. M. R., Howarth, R. B., \& Borsuk, M. E. (2010). Pro-environmental behavior. Annals of the New York Academy of Sciences, 1185(1), 211-224.

van Riper, C. J., \& Kyle, G. T. (2014). Understanding the internal processes of behavioral engagement in a national park: a latent variable path analysis of the value-belief-norm theory. Journal of Environmental Psychology, 38, 288-297. 
Vandenbergh, M. P. (2005). Order without social norms: How personal norm activation can protect the environment. Northwestern University Law Review, 99(3), 1101-1166.

Weiner, B. (2000). Intrapersonal and interpersonal theories of motivation from an attributional perspective. Educational Psychology Review, 12(1), 1-14.

Wong, K. K.-K. (2013). Partial least squares structural equation modeling (PLS-SEM) techniques using SmartPLS. Marketing Bulletin, 24(1), 1-32.

Xiang, Z., \& Gretzel, U. (2010). Role of social media in online travel information search. Tourism Management, 31(2), 179-188.

Ye, Q., Law, R., Gu, B., \& Chen, W. (2011). The influence of user-generated content on traveler behavior: An empirical investigation on the effects of e-word-of-mouth to hotel online bookings. Computers in Human Behavior, 27(2), 634-639.

Zhang, Y., Zhang, H.-L., Zhang, J., \& Cheng, S. (2014). Predicting residents' proenvironmental behaviors at tourist sites: The role of awareness of disaster's consequences, values, and place attachment. Journal Of Environmental Psychology, 40, 131-146.

\section{Appendix: Questionnaire items}

\begin{tabular}{|l|l|}
\hline $\begin{array}{l}\text { 1.Pro-environmental norms and } \\
\text { behavioral intention }\end{array}$ & Items' sources \\
\hline Personal norms & $\begin{array}{l}\text { Harland (2007); Kiatkawsin \& Han (2017); } \\
\text { Vandenbergh (2005); Vining \& Ebreo (1992) }\end{array}$ \\
\hline $\begin{array}{l}\text { 1. I feel a strong personal obligation to } \\
\text { protect the environment when travelling. }\end{array}$ & \\
\hline $\begin{array}{l}\text { 2. I am willing to put extra effort into pro- } \\
\text { environmental behaviour when travelling. }\end{array}$ & \\
\hline $\begin{array}{l}\text { 3. Regardless of what other people do, } \\
\text { because of my own values/principles, I feel } \\
\text { that I should behave in an environmentally } \\
\text { friendly way while group travelling. }\end{array}$ & \\
\hline
\end{tabular}




\begin{tabular}{|c|c|}
\hline $\begin{array}{l}\text { 4. I have the obligation to comply with } \\
\text { destination environmental regulations and } \\
\text { laws. }\end{array}$ & \\
\hline Environmental awareness & Kiatawsin; Han (2017); Shaul \& Tally (2006) \\
\hline $\begin{array}{l}\text { 5. The tourism industry can casue pollution, } \\
\text { climate change, and exhaustion of natural } \\
\text { resources because of the infrastructures } \\
\text { required to cater to a degree number of } \\
\text { tourists. }\end{array}$ & \\
\hline $\begin{array}{l}\text { 6. Tourists' pro-environmental behaviour can } \\
\text { reduce environmental pollution. }\end{array}$ & \\
\hline $\begin{array}{l}\text { 7. Environmental quality will improve a lot if } \\
\text { we choose more pro-environmental travel } \\
\text { mode. }\end{array}$ & \\
\hline $\begin{array}{l}\text { 8. Tourists can casue environmental } \\
\text { deteriorations of the host community such as } \\
\text { wastes and excessive use of } \\
\text { energy/waste/fuel. }\end{array}$ & \\
\hline Environmental responsibility & $\begin{array}{l}\text { Kiatawsin \& Han (2017); Zhang, Zhang, } \\
\text { Zhang, \& Cheng (2014) }\end{array}$ \\
\hline $\begin{array}{l}\text { 9. Not only the government and destination } \\
\text { managers are responsible for protect the } \\
\text { environment in tourism destination, but me } \\
\text { too. }\end{array}$ & \\
\hline $\begin{array}{l}\text { 10. I feel jointly responsible for the } \\
\text { environmental issues in tourism destinations. }\end{array}$ & \\
\hline $\begin{array}{l}\text { 11. Every traveller must take responsibility } \\
\text { for the environmental problems casued during } \\
\text { their trip. }\end{array}$ & \\
\hline Social norms & $\begin{array}{l}\text { Doran, Hanss \& Larsen (2017); Han (2015); } \\
\text { Rajiv Rimal \& Real (2005) }\end{array}$ \\
\hline $\begin{array}{l}\text { 12. Most people who are important to me } \\
\text { think I should conduct pro-environmental } \\
\text { behaviour when travelling. }\end{array}$ & \\
\hline $\begin{array}{l}\text { 13. Most people who are important to me } \\
\text { would want me to conduct pro-environmental } \\
\text { behaviour when travelling. }\end{array}$ & \\
\hline
\end{tabular}




\begin{tabular}{|c|c|}
\hline $\begin{array}{l}\text { 14. Most of my friends and family members } \\
\text { protect the environment when travelling. }\end{array}$ & \\
\hline $\begin{array}{l}\text { 15. Most people who are important to me } \\
\text { would like to pay more for a trip if this helps } \\
\text { to protect the environment. }\end{array}$ & \\
\hline Pro-environmental behavioral intention & Kiatawsin \& Han (2017) \\
\hline $\begin{array}{l}\text { 16. I would try to save water and electricity } \\
\text { when travelling. }\end{array}$ & \\
\hline $\begin{array}{l}\text { 17. I would buy eco or organic products when } \\
\text { possible. }\end{array}$ & \\
\hline $\begin{array}{l}\text { 18. I would learn about the recycling facilities } \\
\text { and actions of the locals when travelling. }\end{array}$ & \\
\hline $\begin{array}{l}\text { 19. I would try to dispose garbage properly if } \\
\text { possible. }\end{array}$ & \\
\hline $\begin{array}{l}20 . \text { I would try to protect local resources as } \\
\text { much as I could when travelling. }\end{array}$ & \\
\hline 2. Social media engagement & $\begin{array}{l}\text { Narangajavana, Fiol, Tena, Artola, \& Garcia } \\
\text { (2017); Lim, Hwang, Kim, \& Biocca (2015) }\end{array}$ \\
\hline $\begin{array}{l}\text { 21. I frequently visit online travel community } \\
\text { and see posts that related to pro- } \\
\text { environmental travel behavior. }\end{array}$ & \\
\hline $\begin{array}{l}\text { 22. When I see pro-environmental travel } \\
\text { related posts on online travel communities, I } \\
\text { usually forward the posts to others, or make a } \\
\text { comment. }\end{array}$ & \\
\hline $\begin{array}{l}\text { 23. When traveling, I usually post my } \\
\text { feelings when I like/dislike others' travel } \\
\text { behavior relating to environment. }\end{array}$ & \\
\hline $\begin{array}{l}\text { 24. I am emotionally connected to the online } \\
\text { travel community which discusses pro- } \\
\text { environmental behavior. }\end{array}$ & \\
\hline
\end{tabular}

